\title{
THE HISTORY AND CULTIVATION OF ETLINGERA - THE TORCH GINGERS - AT THE ROYAL BOTANIC GARDEN EDINBURGH
}

\author{
Helen Yeats ${ }^{1}$
}

\begin{abstract}
The ginger family, Zingiberaceae, is a pan-tropical family comprising 51 genera and c. 1,200 species predominantly found in Asia and the Pacific regions. The collection at the Royal Botanic Garden Edinburgh (RBGE) has been actively researched since the 1950s (Newman, 2000) and taxonomists from a variety of institutions around the world have discovered, described, verified, named and renamed many taxa within this diverse group of plants. One genus, Etlingera, has been extensively worked on recently, with over 30 new species identified from Sulawesi alone and probably between 150 and 200 species altogether within the genus (Poulsen, 2012). A list of the 25 species of Etlingera cultivated at RBGE is provided. Most of these were collected from the wild as seed. Scientific and horticultural field trips to collect members of the ginger family have provided an extensive and ever-expanding unique living research resource and over the last ten years the collection has doubled in size. This paper describes the cultivation of Etlingera at RBGE and discusses some of the features and challenges associated with the genus.
\end{abstract}

\section{INTRODUCTION}

The genus Etlingera is one of the largest in Zingiberaceae, referred to as the ginger family, which includes more than 1,200 species, the best known of which is the common spice - ginger (Zingiber officinale) (Poulsen, 2006). The type specimen of Etlingera was originally collected in southern Thailand by Johann Gerhard König in 1779 as Amomum littorale. It was described in 1792 by Paul Dietrich Giseke and named after the German botanist Andreas Ernst Etlinger. However, it wasn't until nearly 200 years later, in 1986, that B.L. Burtt and Rosemary Smith of RBGE concluded that several species of Etlingera had been incorrectly included in other genera: Nicolaia Horaninow (1862), Achasma Griff. (1851), Geanthus Reinw. (1826), Diracodes Blume (1827) and Phaeomeria (Ridl.), K.Schum. (1904) (Poulsen, 2012). Since then revisions of Etlingera have been made from plants collected in Peninsular Malaysia (Khaw, 2001), Borneo (Smith, 1986b; Poulsen, 2006), Sulawesi (Poulsen, 2012) and Java (Poulsen, 2007; 2012). This range covers a relatively small area given that Etlingera ssp. are found in equatorial evergreen rainforests ranging from Sikkim in India to Tahiti in the Pacific Ocean and from as far north as China to Australia in the south (Poulsen, 2012). Indeed, Poulsen's recent monograph of Etlingera has shown there to be as many as 150-200 species (Poulsen, 2012).

1. Helen Yeats is a Horticulturist in the Indoor Department at the Royal Botanic Garden Edinburgh with responsibility for the care of the Zingiberaceae Research Collection. Address: 20A Inverleith Row, Edinburgh, EH3 5LR. Email: H.Yeats@rbge.org.uk 
RBGE has a strong history of plant collection and research in South-East Asia due to targeted floristic research programmes. Expansion of the Zingiberaceae Living Collection began in the 1960s with collections made by B.L. Burtt and P. Woods in Sarawak (Burtt \& Smith, 1972). This was followed by a significant period between 1970 and 1990 spent by these two workers on the clarification of the taxonomy of Zingiberaceae, a notoriously difficult family to classify. This work continued when Mark Newman was appointed to the scientific staff of RBGE in the 1990s and led to further expansion of the Collection thanks to his research into the family. A steady stream of staff and student projects and wild collections have followed since then, meaning that the Living Collection now comprises 266 species within 33 genera, and a total of 720 accessions accounting for 1,461 plants (see Table 1). This is in contrast to the respective figures in 2001 which were 150 species, 28 genera, 415 accessions and 422 plants (Govier et al., 2001). At that time only two of these were Etlingera species and Appendix 1 provides collection details for the Living Collection of this genus as it stands now. Collecting trips and subsequent taxonomic work by Axel Dalberg Poulsen since the early 2000s on Etlingera in particular has increased numbers of the genus in the Collection. It is thanks in part to his collections and work that that there has been an increase in familiarity with and consequential use of Etlingera and that the author has seen the need to publish this paper on the cultivation of the genus.

Sadly, with present anthropogenic pressures on land and the consequential conversion of forested land to other uses, many rainforest habitats are now greatly degraded, fragmented or lost entirely. Some Etlingera species are found at forest margins and can exhibit vigorous growth in disturbed areas. Etlingera fimbriobracteata (Fig. 1) exhibits such behaviour, but fortunately in Borneo the leafy shoots are useful for making mats. However, many of the Zingiberaceae are found in primary and secondary forests under the shade of taller trees and will not tolerate increased exposure. Removal of the canopy layer modifies the microclimate, alters the nutrient cycling processes, causes erosion and brings about a loss of quality rainforest, reducing diversity of both flora and fauna. Loss of pollinators and seed dispersers further reduces the ability of plant populations to recover from depleted habitats. In the future it is likely that many more members of the ginger family will become scarce (Fig. 2) and further discovery of new taxa may be limited.

The Zingiberaceae are globally and locally important; modern pharmacological research is validating the antioxidant and antibacterial healing properties of medicinal and cosmetic plants used for over 5,000 years (Leong-Škorničková \& Gallick, 2010). They are increasingly grown as ornamental plants (Bordelon \& Kress, 2005) and regularly used in religious ceremonies. Turmeric, aromatic oils from cardamom and a variety of other gingers and their flowers are presented as offerings to Hindu and Buddhist gods (Leong-Škorničková \& Gallick, 2010) and the spices cardamom, ginger, turmeric and Grains of Paradise (Aframomum melegueta) provide flavour in cooking (Legner, 2006). The shoots, flower buds and fruits of Etlingera sp. such as E. elatior (Fig. 3) provide an important food resource for indigenous people: 20 different species of Etlingera are used as a vegetable in Borneo (Poulsen, 2006). 


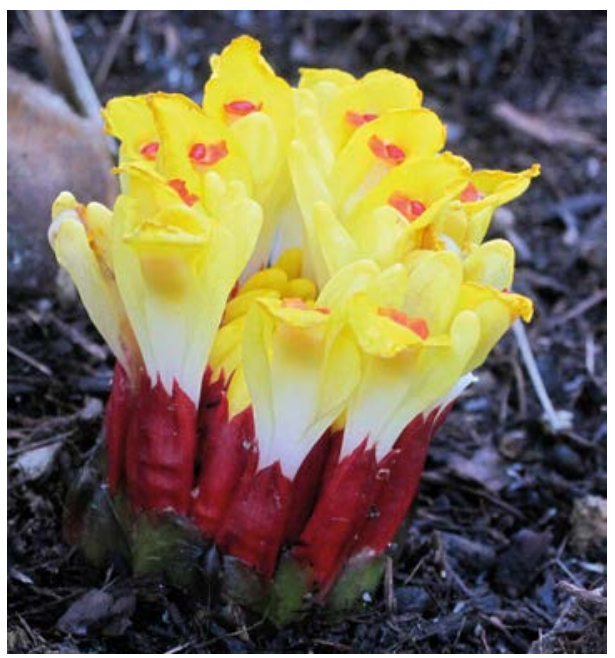

Fig. 1 Etlingera fimbriobracteata. Photo: Helen Yeats.

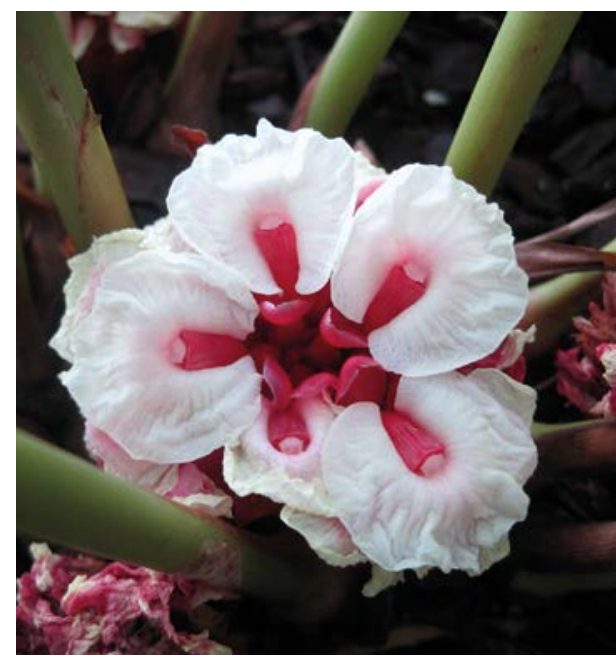

Fig. 2 Endangered Etlingera orbiculata. Photo: Helen Yeats.

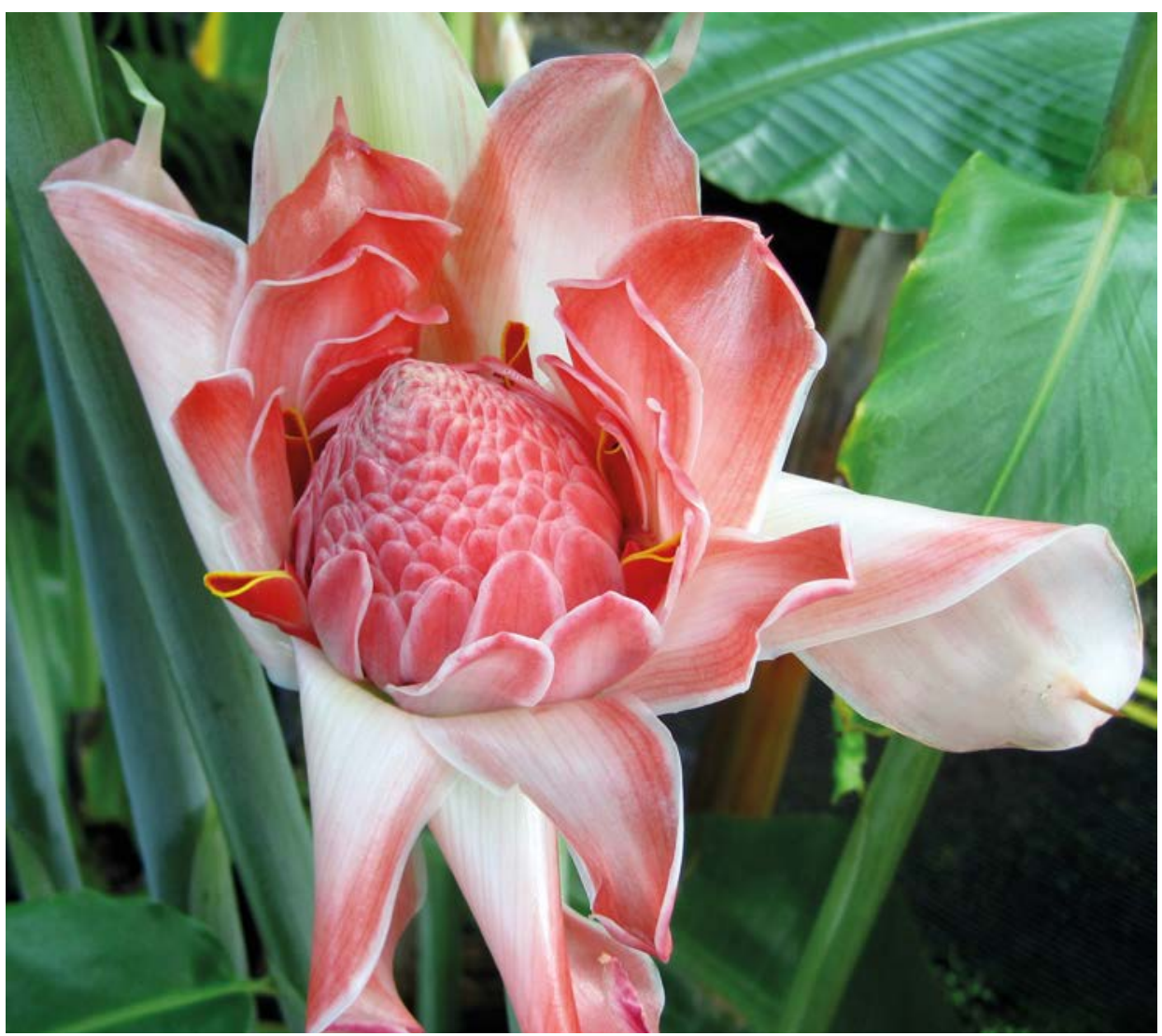

Fig. 3 Etlingera elatior. Photo: Helen Yeats. 


\section{ETLINGERA IN THE LIVING COLLECTION AT THE ROYAL BOTANIC GARDEN EDINBURGH}

The population of Etlingera in the RBGE Living Collection has increased in recent years largely through collections made by a number of expeditions to South-East Asia. This means that the majority of living specimens are of known wild origin with good collection information (see Table 1).

Etlingera is a terrestrial perennial herb which is found between sea level and $2,700 \mathrm{~m}$ and can range in height from less than $50 \mathrm{~cm}$ to nearly $10 \mathrm{~m}$ (see Appendix 1). The larger species have strong, stout, leafy shoots called pseudostems arising from thick rhizomes which become robust with age. Some species are clump-forming in habit while others are more spreading with longer rhizome distances between the leafy shoots. Several Etlingera have stilt roots; these are adventitious support roots growing laterally and downwards from the rhizome (Figs 4 \& 5). Creeping close to the surface through the leaf-litter, the roots provide stability and anchorage on steep slopes in montane habitats and elevate the rhizome from wet ground in lowland forest. The flowering shoot is a cone-like spike composed of bracts and flowers which are held on a peduncle of various lengths. Some inflorescences are partially subterranean such as Etlingera megalocheilos (Figs $6 \& 7$ ) while many are held upright on the long stalks giving the genus the common name of torch ginger (Figs 8 \& 9). Colourful tubular flowers (Figs $10 \& 11$ ) open a few at a time each day and are pollinated by territorial spider-hunter birds (Arachnothera longirostra) and long-tongued Amegilla bees (Poulsen, 2012). The seed is surrounded by a juicy aril and enclosed by the fleshy pericarp of the indehiscent fruit (Fig. 12), which invites consumption by people and other organisms thereby aiding seed dispersal away from the parent plant (Poulsen, 2012).

\begin{tabular}{|l|c|c|}
\hline & \multicolumn{1}{|c|}{ Zingiberaceae } & Etlingera \\
\hline Number of genera & 33 & 1 \\
\hline Number of species & 266 & 25 \\
\hline Number of accessions & 720 & 46 \\
\hline Number of plants & 1461 & 67 \\
\hline Wild origin accessions & 609 & 43 \\
\hline Indirect wild origin accessions & 25 & 1 \\
\hline Garden origin accessions & 81 & 2 \\
\hline
\end{tabular}

Table 1 Summary data from BG-BASE TM (Walter \& O'Neal, 1985-2010) of the collection of Zingiberaceae at RBGE in May 2013. 
Due to their diversity of form and flowering complexity the Zingiberaceae are a fascinating group of plants to grow. Etlingera offer many possibilities for an attractive display in a large glasshouse environment. With their elegant arching habit, varied leaf shape and colour, and interesting flowering torches, they provide an architectural dimension to many planting schemes (Fig. 13).

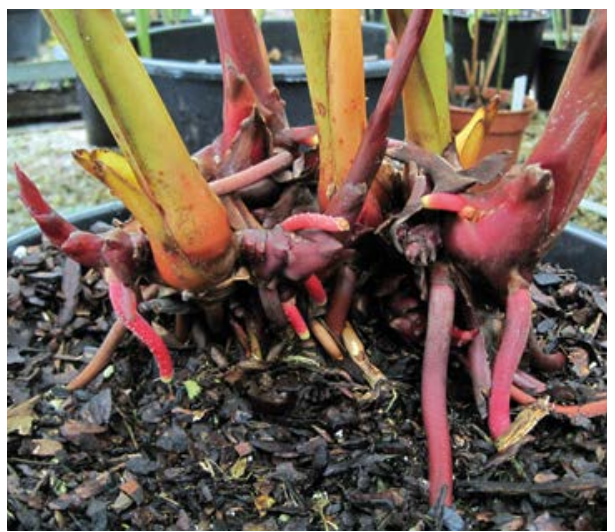

Fig. 4 Stilt roots of Etlingera polycarpa ssp. ligulata. Photo: Helen Yeats.

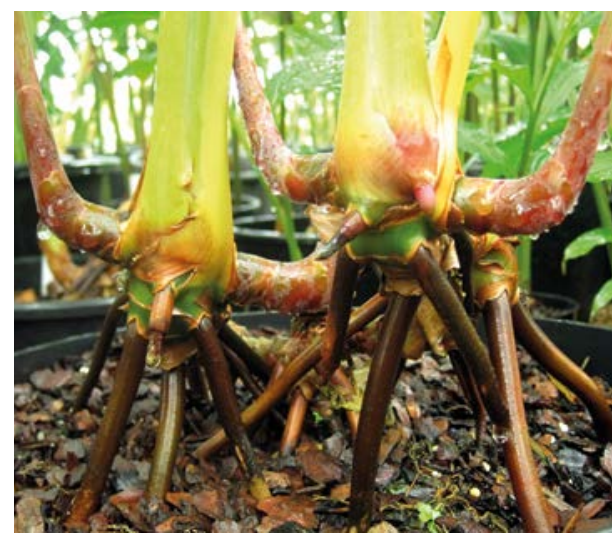

Fig. 5 Stilt roots of Amomum sp., a close relative of the genus Etlingera. Photo: Helen Yeats.

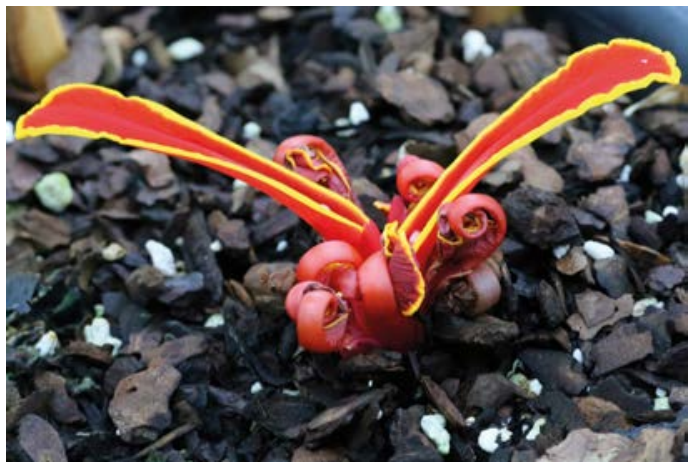

Fig. 6 Etlingera megalocheilos. Photo: Christopher Walker.

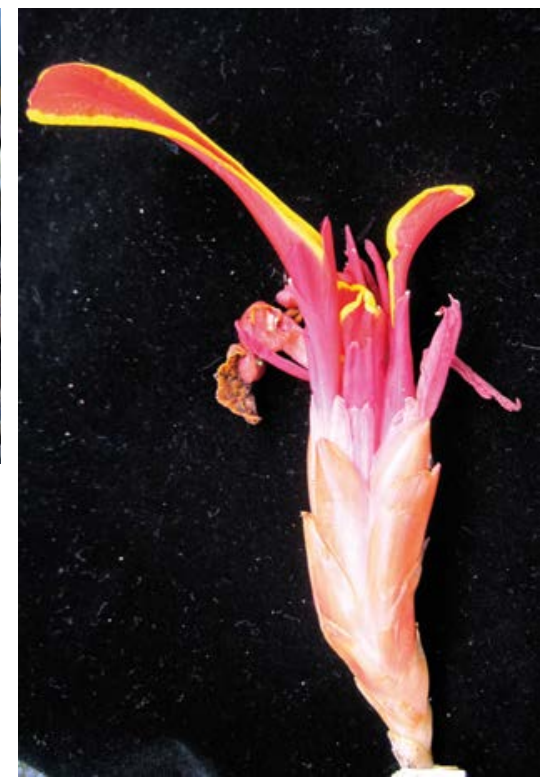

Fig. 7 Etlingera megalocheilos showing the underground section of inflorescence. Photo: Helen Yeats. 


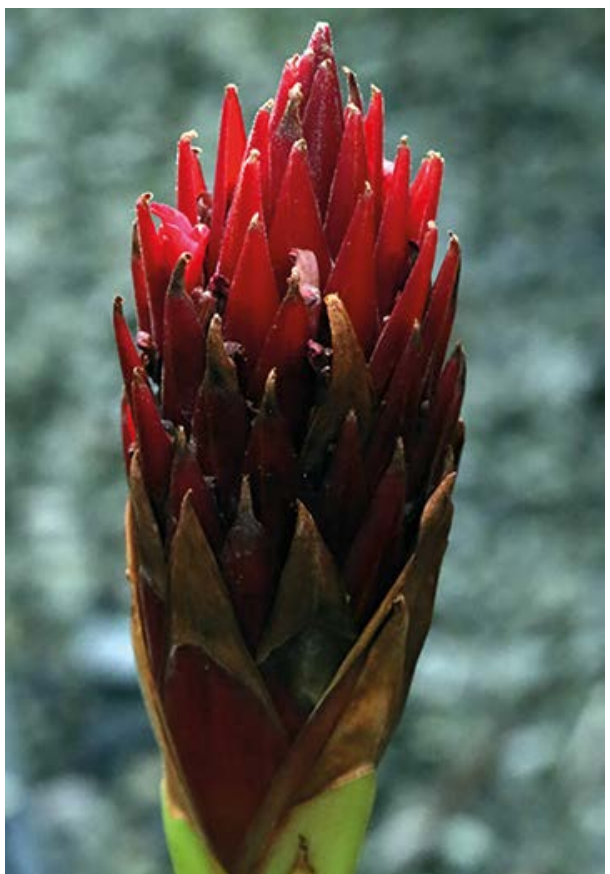

Fig. 8 Torch ginger Etlingera sp. Photo: Christopher Walker.

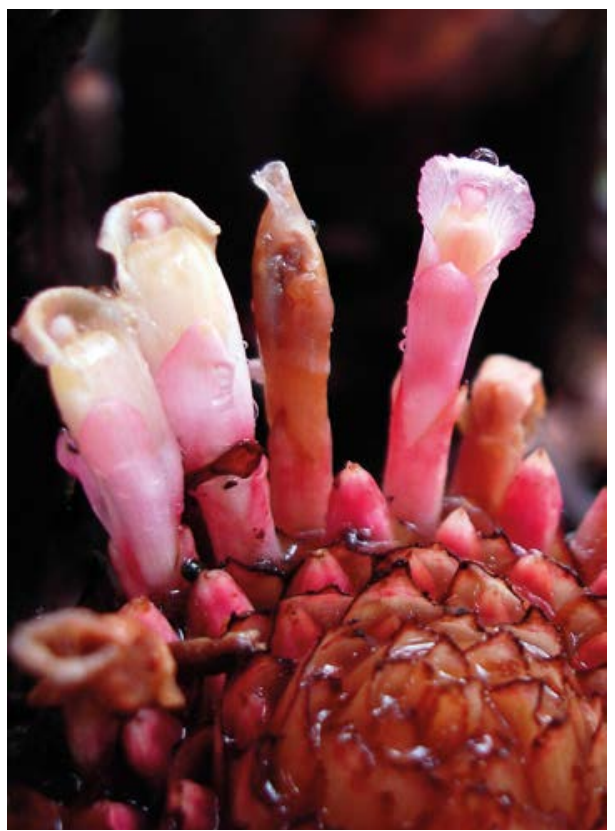

Fig. 10 Etlingera alba. Photo: Helen Yeats.

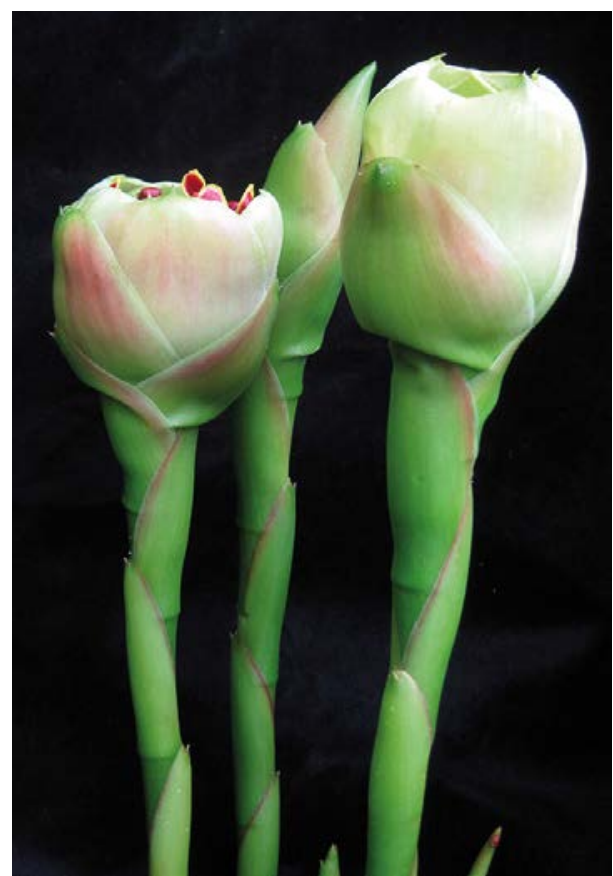

Fig. 9 Torch ginger Etlingera hemisphaerica. Photo: Helen Yeats.

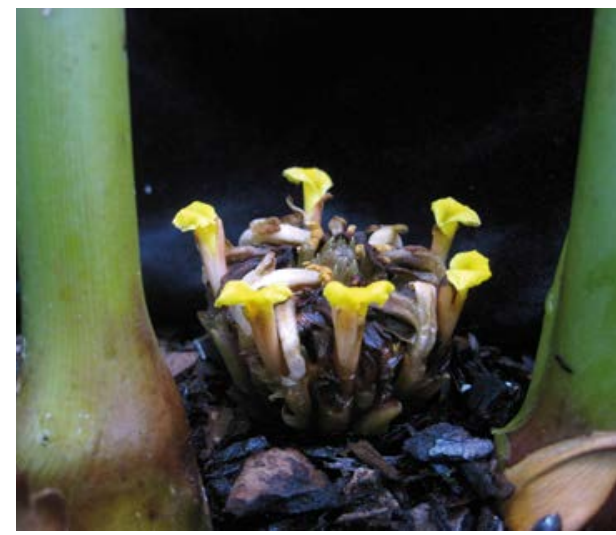

Fig. 11 Etlingera calophrys. Photo: Helen Yeats. 


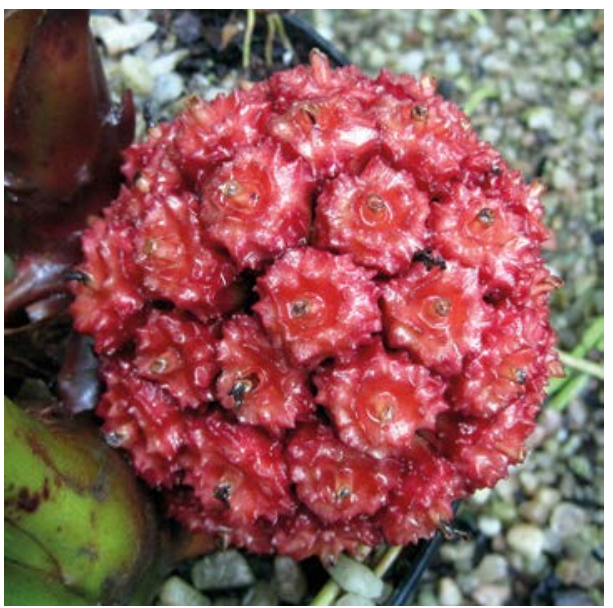

Fig. 12 Large infructescence of Etlingera polycarpa ssp. ligulata. Photo: Helen Yeats.

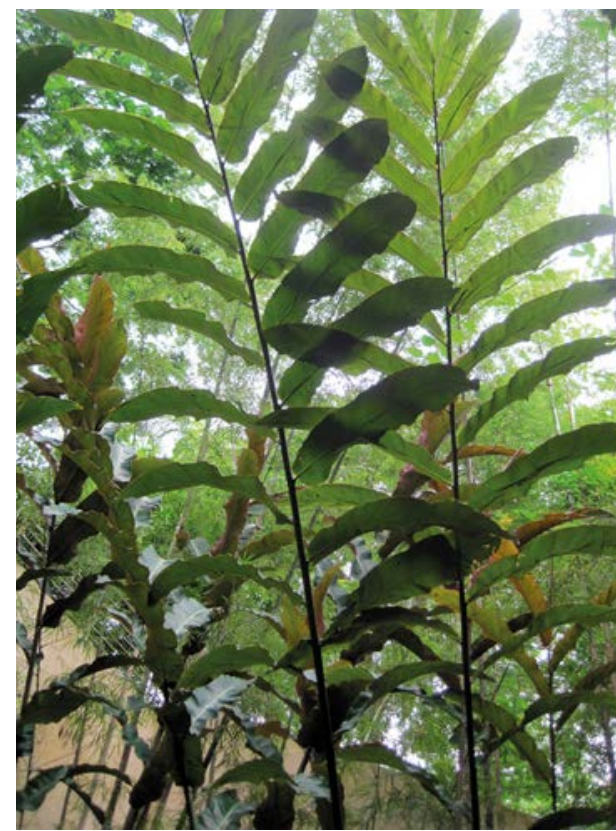

Fig. 13 Architectural pseudostems, a feature of many Etlingera species. Photo: Helen Yeats.

\section{CULTIVATION AND PROPAGATION TECHNIQUES}

Etlingera are demanding plants in their requirements for space, high temperatures $\left(18-25^{\circ} \mathrm{C}\right.$ minimum), high humidity $(80 \%+)$, light in winter, shade in summer and frequent watering. Providing good growing conditions under glass in non-tropical areas is challenging; they grow quickly, requiring regular feeding and frequent repotting (Fig. 14). They need to be shaded during late spring and summer while lack of light over the winter period causes them to grow taller and weaker than they would if grown outside where they are exposed to stronger sunlight and air movement. This difference in plant size and growth habits of glasshouse-grown plants can sometimes perplex taxonomists if, for example, the inflorescence is smaller or the plant is larger than expected. However, when measuring the diagnostic features, such as corolla size and distance between nodes or pseudostems, they are found to be proportionally equal to the wild collected plants. Despite such morphological anomalies in cultivation there is still enormous value in being able to examine groups of plants in one location. The Living Collection at RBGE provides a vital and unique resource for researchers, allowing closer, more detailed study of actively growing plants than would be possible in the wild. This is particularly true for the study of the Zingiberaceae because investigation of these plants in the rainforest is difficult; the flowers last only one day, they are often covered in mucilage or damaged by animals and diagnostic features of the flowers are compromised when pressed and dried and so they have to be preserved in alcohol to keep them intact. 


\section{Vegetative propagation}

When grown in the glasshouses clumps of Etlingera are kept within their allocated space by regular division. Over time the thick rhizomes become very tough and fibrous and a sharp implement is required to divide the plant. Some of the larger species quickly outgrow their space and after a few years the whole plant needs to be dug up and split. This disturbance will be tolerated by the plant if undertaken during its growing season and it will establish better if a clump of rhizome with at least two or three leafy shoots is taken and potted up. The roots can be shortened by one-third to a half and older rhizomes and dead roots pruned out. The pseudostems should be reduced by about one-half to two-thirds to prevent too much water loss through transpiration. Divided plants should be potted up with free-draining compost, with the rhizome lightly covered; burying it too deeply will cause it to rot. Bottom heat will encourage rooting but this is not practical with larger plants.

Cuttings are most easily taken from the younger growth located at the outer edges of the clump or pot. A section of rhizome $15-25 \mathrm{~cm}$ long, with at least one developed leafy shoot and several growth buds, is cut away from the plant, potted into a shallow seed tray with free-draining compost and watered in. Cuttings are placed in a propagation case with bottom heat and high humidity until rooted. If cuttings are taken in winter they will take longer to root because of low light levels and are likely to rot if over-watered.

The large Etlingera are labour-intensive when grown in containers as they quickly outgrow their space and nutrients in the substrate and have to be pruned and repotted every one to two years. Stilt-rooted plants resent disturbance and should be carefully divided, keeping as much of the root system intact as possible. The leafy shoots are also shortened and supported with canes until new stilt roots are able to provide their own support. Once repotted, the plants are watered to settle in the compost around the roots. Careful watering and misting from then on is necessary until active growth is noticed because plants are again susceptible to rot following root disturbance.

\section{Seed propagation}

Fresh Etlingera seed germinates much more quickly than dried and viability greatly decreases with age. Most fresh seed germinates within the first two months of sowing; the fastest germination time recorded by the author is 15 days, while dried seed can take up to a year. Dried seeds are soaked for several hours in order to soften the tough seed coat. Changing the water during the soaking process helps to flush out any growth inhibitors that may be present. The seeds are sown into $5-10 \mathrm{~cm}$ pots of sieved fine bark compost which is sterilised by pouring boiling water over the pots, and lightly covered with a thin layer of compost no deeper than the depth of the seed. Pots are placed in a plastic bag and sealed to keep moisture in and pests out, and placed in a heated propagator with a temperature of $25-30^{\circ} \mathrm{C}$. As soon as the seeds have germinated 


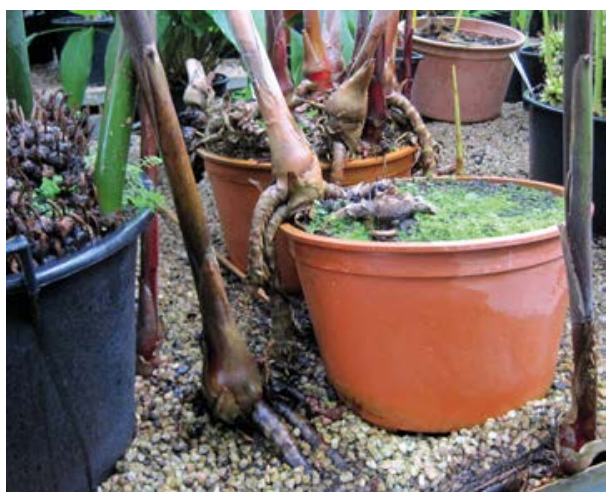

Fig. 14 When the growing conditions are not quite right Etlingera sp. roots seek preferable conditions. Photo: Helen Yeats.

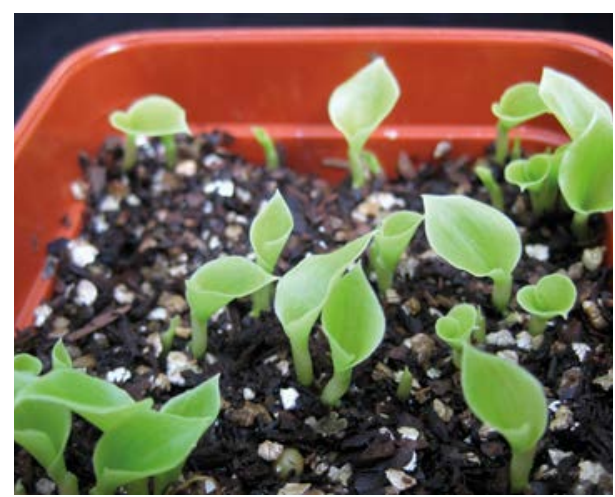

Fig. 15 Three-week-old seedlings of Etlingera minor ready for pricking out. Photo: Helen Yeats.

(Fig. 15), often after one to four months, they can be removed from the heat. After the first leaves have appeared the bag is opened to prevent condensation on the inside of the bag damaging new leaves. Once they have acclimatised to cooler conditions the bag is removed and the seedlings pricked out into individual pots. It is important not to over-pot the seedlings as too much moisture in larger pots will rot the roots and newly forming rhizome. Sometimes germination can be sporadic, with one or two individuals appearing at first and several more sprouting a month or two later. If fewer than three seeds germinate, the pot with the ungerminated seed is returned to the heat in the hope that more will grow. After nine months it is very unlikely that more seed will germinate and the pots are discarded.

\section{Growing medium}

At RBGE Etlingera are grown in soil-less compost comprising large and medium-sized composted bark (see Table 3 in Appendix). Perlite, vermiculite and horticultural charcoal are added to help keep the mixture open and free-draining but moisture-retentive. Dolomitic limestone provides magnesium, and trace elements and slow-release granular fertiliser are added to the mix to provide essential nutrients. These are quickly used up and supplementary liquid feeding every few weeks throughout the growing season is necessary. During spring and early summer plants are fed with a proprietary fertiliser with an N:P:K ratio of 3:1:1, a balanced 1:1:1 feed is used over summer and towards the end of the season 3:1:6 is used to toughen the plants for the winter and to encourage flowering the following season. The plants are checked daily and watered when the top layer of compost is dry. High humidity is achieved by damping down benches and pathways at regular intervals and occasionally misting over the plants with a fine spray. Plant growth slows down during the winter and watering is more considered as the rhizomes will rot if kept too wet. 


\begin{tabular}{|l|l|l|l|}
\hline \multicolumn{1}{|c|}{ Ingredients } & \multicolumn{1}{|c|}{ Particle size } & \multicolumn{1}{c|}{ Amount } & \multicolumn{1}{c|}{ Brand used } \\
\hline Potting bark & $3-15 \mathrm{~mm}$ & 2101 & Melcourt \\
\hline Propagation bark & $2-7 \mathrm{~mm}$ & 2101 & Melcourt \\
\hline Charcoal & $3-15 \mathrm{~mm}$ & 151 & Various suppliers \\
\hline Vermiculite & $2-5 \mathrm{~mm}$ & 151 & Sinclair Professional \\
\hline Perlite & $2-5 \mathrm{~mm}$ & 151 & Sinclair Professional \\
\hline Slow-release fertiliser & $2-3 \mathrm{~mm}$ & $500-700 \mathrm{~g}$ & Osmocote ${ }^{2}$ 12-14m \\
\hline Dolomitic limestone & $<1 \mathrm{~mm}$ & $300 \mathrm{~g}$ & Various suppliers \\
\hline Trace elements & $<1 \mathrm{~mm}$ & $300 \mathrm{~g}$ & Chase Seaweed Meal \\
\hline
\end{tabular}

Table 3 General compost mix for Zingiberaceae.

\section{Pest control}

Pests of Etlingera under glass include mealy-bugs, root aphids, ants, cockroaches, spider-mites, scale, slugs and worms. A regular regime of mechanical, biological and chemical pest control combined with good glasshouse hygiene is necessary to limit the damage. Most harm is caused by scale and mealy-bugs sucking nutrients and moisture from the growing leaf tips or flowering buds. These pests are checked for regularly and when numbers increase to unacceptable levels they are controlled using an insecticide such as $\mathrm{BANDU}^{\mathrm{TM}}$, a pyrethroid insecticide based on deltamethrin $25 \mathrm{~g} / 1(2.8 \% \mathrm{w} / \mathrm{w})$. Ants further exacerbate the aphid problem because they 'farm' the mealy-bugs and scale by actively moving them to the soft plant growth and harvest the honeydew excreted by them to feed to their young in ant nests in the pots. Repotting helps to reduce ant, root aphid, worm and cockroach numbers but total eradication of pests within the glasshouse is almost impossible. Spider-mite can be a problem during spring when light levels increase and the glass has not yet been shaded but the cold weather outside requires a higher heating input, resulting in drier conditions. When this occurs air circulation is improved, shading applied and the humidity increased and this usually reduces the egg-laying rate of the mites and overcomes the problem. Spider-mite can also be biologically controlled with its natural predator Phytoseiulus persimilis. Cockroach and slug damage on young growth are controlled with slug pellets, cockroach traps and by practising good hygiene. Biological control of slugs using nematodes, Nemaslug ${ }^{\circledR}$ and control of sciarid flies using Hypoaspis miles, a predatory mite, can be effective. 


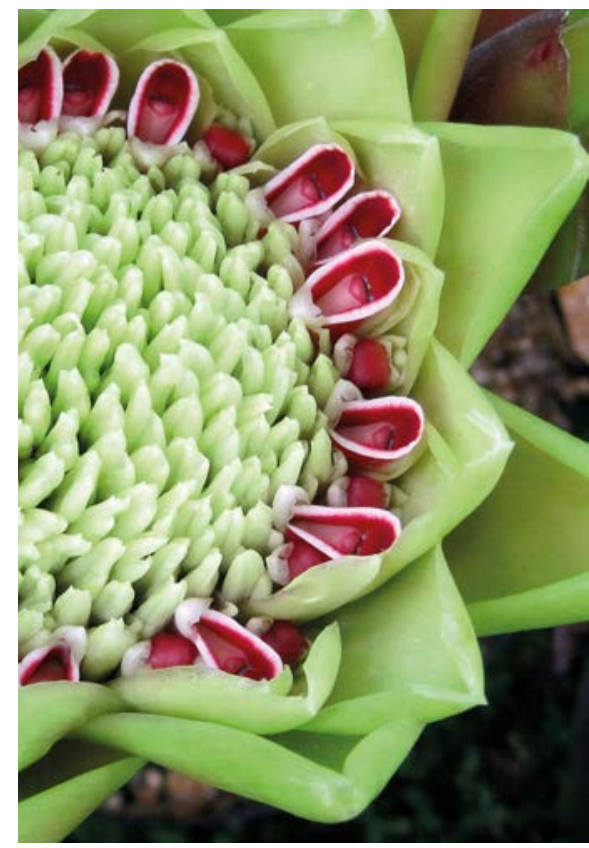

Fig. 16 Inflorescence of Etlingera loerzingii. Photo: Helen Yeats.

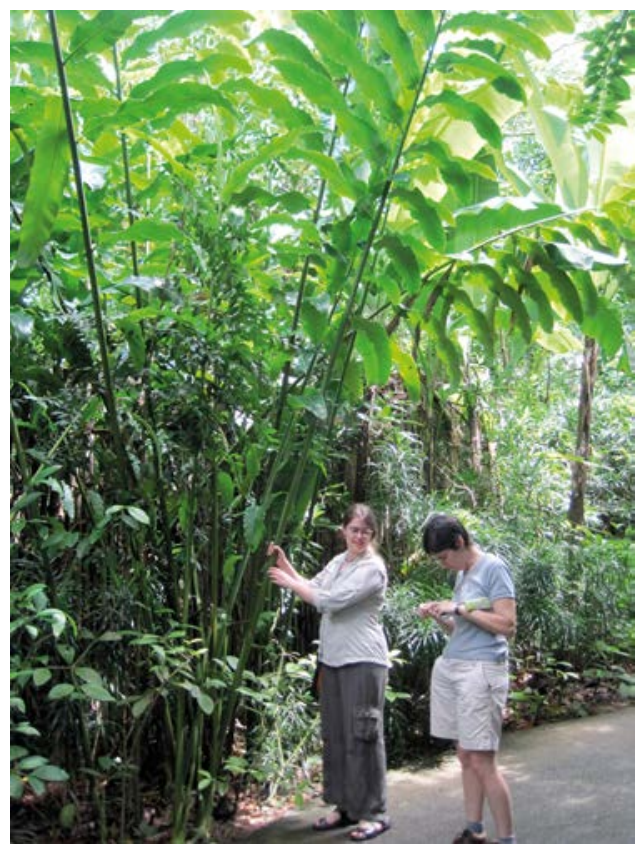

Fig. 17 Towering stems of Etlingera elatior with researchers Jane Droop and Kaylene Bransgrove in the foreground at Singapore Botanic Gardens. Photo: Helen Yeats.

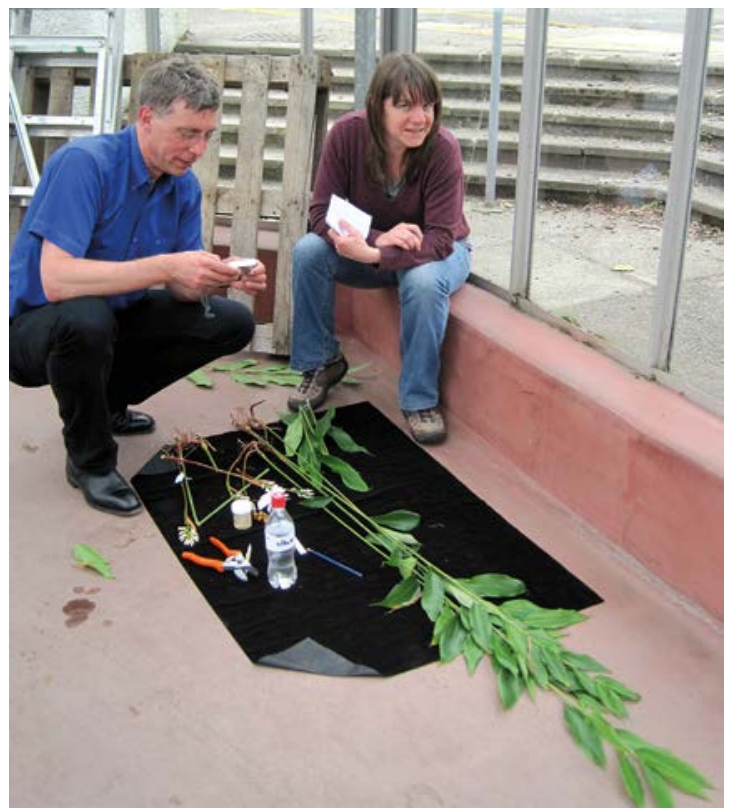

Fig. 18 Researchers Axel Dalberg Poulsen and Nicky Sharp take herbarium voucher specimens of the Living Collection at RBGE. Photo: Helen Yeats. 


\section{SUMMARY}

Etlingera are interesting plants to grow in tropical biomes of botanic gardens, providing both an ornamental and an architectural element to planting schemes (Figs 16 \& 17). Living collections provide an excellent resource for educational purposes and enable closer taxonomic study (Fig. 18). However, when grown in pots the plants are often compromised and extra nurturing is essential to ensure healthy plants. The ever-expanding collection of gingers at RBGE encompasses a wide range of genera from a variety of climatic zones and specialised habitats (see Appendix 1). Although these conditions are not easy to replicate in the glasshouse environment, good collection notes taken during the acquisition of wild plants and the subsequent dissemination of such information from taxonomists to horticulturists facilitate greater understanding of the growing conditions required for the cultivation of the Living Collection. More information on the Living Collection at RBGE is available at www.rbge.org.uk/science/tropical-diversity/ Monographic-phylogenetic-research/zingiberaceae\#The_ginger_family

\section{ACKNOWLEDGEMENTS}

The author would like to thank the following individuals for their help: Kate Hughes, Mark Newman, Axel Dalberg Poulsen and Helen Thompson.

\section{REFERENCES}

BORDELON, M. \& KRESS, J. (2005). Tropical ginger cultivation in North American temperate climates. Sibbaldia, 3, 83-91.

BURTT, B.L. \& SMITH, R.M. (1972). Key species in the taxonomic history of Zingiberaceae. Notes from the Royal Botanic Garden Edinburgh, 31, 177-227.

GOVIER, R., WALTER, K.S., CHAMBERLAIN, D., GARDNER, M., THOMAS, P., ALEXANDER, C., MAXWELL, H.S. \& WATSON, M.F. (2001). Catalogue of Plants 2001. Royal Botanic Garden Edinburgh.

LEGNER, E.F. (2006). Plants of Economic or Aesthetic Importance: Spices and Other Flavouring Substances. Available online: www.faculty.ucr.edu/ legneref/botany/index.html (accessed June 2013).

LEONG-ŠKORNIČKOVÁ, J. \& GALLICK, D. (2010). The Ginger Garden. Singapore: National Parks Board, Singapore Botanic Gardens.

NEWMAN, M. (2000). Seven years on the spice route. The Botanics, 3, 6-8.

POULSEN, A.D. (2006a). Etlingera of Borneo. Sabah: Natural History Publications.

POULSEN, A.D. (2006b). Gingers of Sarawak. Kota Kinabalu: Natural History Publications (Borneo) Sdn. Bhd.

POULSEN, A.D. (2012). Etlingera of Sulawesi. Kota Kinabalu: Natural History Publications (Borneo) Sdn. Bhd. 
WALTER, K.S. \& O'NEAL, M.J. (1985-2010). BG-BASE ${ }^{\text {tM }}$ (Collection Management Software) BG-BASE inc. BG-BASE (UK) Ltd. Available online: www.bg-base.com (accessed April 2013).

WHITMORE, T.A. (1992). Tropical Deforestation and Species Extinction. London: Chapman and Hall. 


\section{APPENDIX 1}

The table below lists the Living Collection of Etlingera at the Royal Botanic Garden Edinburgh (RBGE). The accession number is the unique number the plant material has been given on entering the Collection. The first four digits are the year of accession and therefore give an indication of the year of collection from the wild. The habitat descriptions are the notes taken by the collector and recorded in the RBGE plant records database $B G-B A S E^{\mathrm{TM}}$. N/d indicates that no data is available for this accession. 'Altitude' is the metres above sea level at which the plant was collected.

\begin{tabular}{|c|c|c|c|c|}
\hline $\begin{array}{c}\text { Accession } \\
\text { number }\end{array}$ & Species name & Country & $\begin{array}{l}\text { Altitiude } \\
\quad(\mathbf{m})\end{array}$ & Habitat description \\
\hline 20051696 & Etlingera & Sumatra & $950 \mathrm{~m}$ & $\mathrm{n} / \mathrm{d}$ \\
\hline 20051699 & Etlingera & Sumatra & $850 \mathrm{~m}$ & $\begin{array}{l}\text { Protected forest but very } \\
\text { disturbed }\end{array}$ \\
\hline 20070110 & Etlingera & Papua New Guinea & $1,800 \mathrm{~m}$ & $\begin{array}{l}\text { Montane forest margin next to } \\
\text { cultivated land }\end{array}$ \\
\hline 20080595 & Etlingera & Papua New Guinea & $115 \mathrm{~m}$ & $\begin{array}{l}\text { Forested slope of river gorge } \\
\text { near gardens }\end{array}$ \\
\hline 20080599 & Etlingera & Papua New Guinea & $800 \mathrm{~m}$ & Roadside forest, disturbed \\
\hline 20090849 & Etlingera & Papua (Irian Jaya) & $912 \mathrm{~m}$ & $\begin{array}{l}\text { Forest relatively unspoilt, steep } \\
\text { mountain sides, orange clay soil }\end{array}$ \\
\hline 20110265 & Etlingera & Kalimantan & $737 \mathrm{~m}$ & Right next to a stream, sandy soil \\
\hline 20110279 & Etlingera & Kalimantan & $1,400 \mathrm{~m}$ & Sub-montane rainforest \\
\hline 20021849 & E. alba & Sulawesi & $340 \mathrm{~m}$ & $\begin{array}{l}\text { Growing in deep shade on wet } \\
\text { soils next to old logging track }\end{array}$ \\
\hline 20061115 & E. alba & Indonesia & $\mathrm{n} / \mathrm{d}$ & $\mathrm{n} / \mathrm{d}$ \\
\hline 20080604 & E. alba & Indonesia & $375 \mathrm{~m}$ & Forest margin \\
\hline 20081006 & E. aulocheilos & Sulawesi & $625 \mathrm{~m}$ & $\begin{array}{l}\text { Strongly disturbed forest margin } \\
\text { next to abandoned plantation }\end{array}$ \\
\hline 20080410 & E. calophrys & Sulawesi & $800 \mathrm{~m}$ & $\begin{array}{l}\text { Gardens and secondary forest } \\
\text { near trail }\end{array}$ \\
\hline 20080418 & E. calophrys & Indonesia & $\mathrm{n} / \mathrm{d}$ & $\mathrm{n} / \mathrm{d}$ \\
\hline 20090620 & E. calophrys & Sulawesi & $\mathrm{n} / \mathrm{d}$ & $\begin{array}{l}\text { Roadside, disturbed vegetation } \\
\text { in forest }\end{array}$ \\
\hline 19981703 & E. elatior & Garden origin & $\mathrm{n} / \mathrm{d}$ & $\mathrm{n} / \mathrm{d}$ \\
\hline 20051701 & E. elatior & Malaysia & $760 \mathrm{~m}$ & $\begin{array}{l}\text { Deep, narrow, heavily shaded } \\
\text { valley }\end{array}$ \\
\hline 20121610 & E. elatior & Garden origin & $\mathrm{n} / \mathrm{d}$ & $\mathrm{n} / \mathrm{d}$ \\
\hline 20000517 & E. elegans & Sulawesi & $1,300 \mathrm{~m}$ & Sub-montane ridge forest \\
\hline 20051848 & E. fimbriobracteata & Sarawak & $250 \mathrm{~m}$ & $\mathrm{n} / \mathrm{d}$ \\
\hline
\end{tabular}




\begin{tabular}{|c|c|c|c|c|}
\hline $\begin{array}{c}\text { Accession } \\
\text { number }\end{array}$ & Species name & Country & $\begin{array}{l}\text { Altitiude } \\
\quad(\mathbf{m})\end{array}$ & Habitat description \\
\hline 20040524 & E. flavovirens & Sulawesi & $900 \mathrm{~m}$ & $\begin{array}{l}\text { Damp, very poor soils, } \\
\text { seasonally dry spell }\end{array}$ \\
\hline 20021880 & E. heliconiifolia & Sulawesi & $970 \mathrm{~m}$ & $\begin{array}{l}\text { Open position on side of large } \\
\text { rock fall, poor soil }\end{array}$ \\
\hline 20080607 & E. heliconiifolia & Sulawesi & $1,100 \mathrm{~m}$ & Secondary forest \\
\hline 20080609 & E. heliconiifolia & Sulawesi & $1,250 \mathrm{~m}$ & Open forest, regularly burnt \\
\hline 20061116 & E. hemisphaerica & Indonesia & $300 \mathrm{~m}$ & Next to road \\
\hline 20081001 & E. hyalina & Sulawesi & $1,100 \mathrm{~m}$ & $\begin{array}{l}\text { Waterlogged soil, full shade, } \\
\text { mossy }\end{array}$ \\
\hline 20100744 & E. cf. littoralis & Cambodia & $\mathrm{n} / \mathrm{d}$ & $\mathrm{n} / \mathrm{d}$ \\
\hline 20040693 & E. loerzingii & Sumatra & $600 \mathrm{~m}$ & $\begin{array}{l}\text { Arboretum: open park with trail } \\
\text { system. Probably not planted }\end{array}$ \\
\hline 20112009 & E. maingayi & Malaysia & $\mathrm{n} / \mathrm{d}$ & $\begin{array}{l}\text { Disturbed area, forest margin, } \\
\text { favours smooth terrain }\end{array}$ \\
\hline 20081040 & E. megalocheilos & Vietnam & $\mathrm{n} / \mathrm{d}$ & $\mathrm{n} / \mathrm{d}$ \\
\hline 20040692 & E. minor & Sumatra & $20 \mathrm{~m}$ & $\begin{array}{l}\text { Slope on a small hill near river } \\
\text { in secondary forest }\end{array}$ \\
\hline 20021196 & E. orbiculata & Sulawesi & $1,340 \mathrm{~m}$ & $\begin{array}{l}\text { Damp rocky ground, dense } \\
\text { shade, little ground cover }\end{array}$ \\
\hline 20080608 & E. pausodipsus & Sulawesi & $1,125 \mathrm{~m}$ & Secondary forest \\
\hline 20021866 & $\begin{array}{l}\text { E. polycarpa } \mathrm{ssp} \text {. } \\
\text { ligulata }\end{array}$ & Sulawesi & $430 \mathrm{~m}$ & $\begin{array}{l}\text { Primary lowland rainforest } \\
\text { Dense canopy }\end{array}$ \\
\hline 20080415 & $\begin{array}{l}\text { E. polycarpa ssp. } \\
\text { ligulata }\end{array}$ & Sulawesi & $950 \mathrm{~m}$ & Roadside in primary forest \\
\hline 20080606 & $\begin{array}{l}\text { E. polycarpa ssp. } \\
\text { ligulata }\end{array}$ & Sulawesi & $1,300 \mathrm{~m}$ & Open, shrubby vegetation \\
\hline 20081003 & $\begin{array}{l}\text { E. polycarpa ssp. } \\
\text { ligulata }\end{array}$ & Sulawesi & $700 \mathrm{~m}$ & $\mathrm{n} / \mathrm{d}$ \\
\hline 20090630 & E. rubroloba & Sulawesi & $100 \mathrm{~m}$ & $\begin{array}{l}\text { By roadside in secondary forest } \\
\text { and plantation area }\end{array}$ \\
\hline 20021202 & E. sarasinorum & Sulawesi & $1,460 \mathrm{~m}$ & $\begin{array}{l}\text { Dense forest, mossy ground; } \\
\text { area very damp and cold }\end{array}$ \\
\hline 20090627 & E. sarasinorum & Sulawesi & $650 \mathrm{~m}$ & In gap above stream \\
\hline 20040939 & E. solaris & Java & $1,100 \mathrm{~m}$ & Bank of small stream \\
\hline 20040653 & E. steringophora & Sulawesi & $1,320 \mathrm{~m}$ & Wet and boggy; area often floods \\
\hline 20051690 & E. subulicalyx & Sumatra & $1,400 \mathrm{~m}$ & Disturbed forest \\
\hline 20080411 & E. tubilabrum & Sulawesi & $800 \mathrm{~m}$ & $\begin{array}{l}\text { Forest margin opposite coffee } \\
\text { plantation }\end{array}$ \\
\hline
\end{tabular}


